\title{
Zero-Base Budgeting for Libraries: A Second Look
}

\begin{abstract}
"Zero-base budgeting" (ZBB) was given considerable attention in the management literature during the latter 1970s. ZBB offers many concepts and budgeting techniques that may prove especially useful to library administrators in the budget-tight 1980s. This article includes a brief review of the key features of $\mathrm{ZBB}$ as a budgeting/planning system, a discussion of the applications of $\mathrm{ZBB}$ reported in the literature, and a summary of the special benefits and problems for libraries that use of concepts derived from $\mathrm{ZBB}$, if not $\mathrm{ZBB}$ itself, might provide.
\end{abstract}

\section{$\mathrm{T}$}

he Carter administration has come and gone, and with it much of the earnest discussion about the virtues of "zero-base budgeting" (ZBB), that much-heralded 1970s tool of budgetary analysis and control. But is there yet value to be found in ZBB? What elements, what concepts, what ideas embodied in $\mathrm{ZBB}$ might be of continuing use to libraries and other service organizations facing the budget-cutting demands of the 1980s? How might library administrators assess ZBB now?

As with so many other issues, the library manager might well first turn to the work of Peter Drucker to gain a better perspective, to find a framework within which ZBB may be examined. Drucker observes that "few managers attempt to think through the changed circumstances in which they operate. Most believe that all that is required is to run harder and to raise more money." Including librarians in his audience, Drucker asserts that the manager "must constantly ask the unpopular question: 'Knowing what we now know, would we get into this activity, this service, this effort if we were not already in it?' " Drucker's instruction to any manager who answers in the negative is clear and to the point: "He should find a way to get out of that service as quickly as possible. At the very least, he should ask himself how methods should be changed to accomplish what his

William J. Crowe is assistant to the director, University Libraries, Ohio State University. institution originally set out to accomplish."1 In the same vein, Herbert White's advice to librarians of the 1970s and 1980s to "take increasingly hard looks at the tasks we perform, the services we provide, the materials we acquire . . . using advanced techniques of measurement and cost-effectiveness evaluation," admits to the pain, but stresses the opportunities, that "strong management [and] intense critical examination" offer. ${ }^{2}$

For library administrators to act on the advice offered by Drucker and White, they must know with some confidence what the library is doing, be able to determine the costs of the library's activities, have methods to evaluate how well those activities correspond to the expressed priorities of the library, and then work to develop means to effect any needed changes by reallocating the library's resources. These are of course the basic components of any well-ordered management program of analysis, planning, program execution, and evaluation. At the center of this management process must be the budget, the vehicle that brings together and displays much of the information required both to analyze and evaluate the library's operations and to make decisions about the future direction of the organization. Whatever form or structure of budgetary system is used by a library, indeed any organization, it must, therefore, meet one critical test: Does it provide timely information of adequate quality and sufficient detail needed by the people who make and execute policy? 
Toward this end, government and business have been subject to several waves of budgetary/management theory since the 1930s: performance budgeting, program budgeting, PPBS (planning, programming, and budgeting system), and, most recently, ZBB. These systems all share an overarching objective: to assist managers in building a rational budgeting structure to replace what has often appeared to be a highly confused, unreasoned (i.e., "political") process for organizational decision making. The impact of these systems on libraries in the United States has not so much been one of wholesale adoption, but in many instances the adaptation of some of the tools and techniques employed by these systems. Cost-analysis and system analysis, for example, are management tools often cited in the literature of library management and are now familiar to many library administrators.

ZBB has only recently been discussed in any depth in library-related literature. Indeed, Martin's Budgetary Control in Academic Libraries (1978) makes only passing reference to the subject. ${ }^{3}$ Charles W. Sargent, in the January 1978 issue of the Bulletin of the Medical Library Association, provides a very basic description of $\mathrm{ZBB}$ and its hypothetical application in a library, but he does not discuss at any length the possible organizational consequences for a library that might adopt ZBB. ${ }^{4}$ An effort at implementing the terminology and display format of ZBB (although not the process itself) at the Lockwood Library of the State University of New York at Buffalo was reported by Diane C. Parker and Eric J. Carpenter later in $1978 .{ }^{5}$ But it was not until 1980 that the library literature included a book-length compendium on ZBB, Ching-chih Chen's ZeroBase Budgeting in Library Management: A Manual for Librarians, ${ }^{6}$ based in large part on material covered by the author during institutes offered on ZBB in 1978. ZBB, in theory and application, is still best described in several general works, the best of them the seminal Zero-Base Budgeting: A Practical Management Tool for Evaluating Expenses, by Peter Pyhrr, the father of ZBB. ${ }^{7}$

In order to evaluate the potential value of ZBB, or ZBB-related ideas, for libraries (and before outlining its major elements), it is essential to keep in mind the budgetary con- cepts included in a brief statement (made in pre-ZBB 1952) by Verne B. Lewis:

The basic objective of budget analysis is the comparison of the relative value of results to be obtained from alternative uses of funds. . . ; costs and results must be considered together. The costs must be judged in relation to the results and the results must be worth their costs in terms of alternative results that are foregone or displaced. ${ }^{8}$

[Emphasis added.]

The distinctive feature of $\mathrm{ZBB}$, as a budgeting system, has been its insistence that operating managers (e.g., department or branch heads in a library) participate actively in the budgeting process by analyzing the operations of their units, categorizing each into discrete "decision packages," and then ranking the packages according to their judgment of the importance of the activity. Each decision package must include (1) a succinct statement of the purpose and value of the activity, (2) cost analysis, (3) alternative means (and costs) for achieving the same purpose, (4) measures of performance (with a statement of the consequences for not performing the activity), and (5) a statement of the benefits of the activity. Subsequently, the manager's supervisors at each level of responsibility review and rank all packages in the larger organizational context. This is, of course, only a brief description of what can become a very complex process.

Accounts of the planning and training required to implement ZBB, especially in state governments, and of the frustrations and difficulties encountered during and after implementation, have been vividly described. The reports of benefits derived from the process, however, are in some cases presented with equal fervor. What some administrators have seen as a major flaw in ZBB, others view as an asset. The most telling example of this conflict of views is an often strongly expressed difference of opinion about the desirability of any substantive involvement by lower- and middle-level managers in the budgeting process. Widely reported as a benefit to the organization's overall management, active participation in budgeting by unit managers is also often represented as imposing far too heavy a burden on people whose skills, abilities, and experience should be more properly employed in the oversight of the day-to-day operation of their units. ${ }^{9}$ 
Much of the criticism that was directed at PPBS in the 1960s, and much of the same sometimes cynical suspicion, has been repeated by critics of ZBB. Administrators whose operations have been justified by precedent, political considerations, and subjective judgment are often skeptical of "total systems" that promise more, or seem to promise more than what they view as practicable. Pyhrr has attempted to answer such critics by stressing the differences between PPBS and $\mathrm{ZBB}$, especially by describing critical gaps in PPBS:

1. PPBS focuses on what will be done, not how to do it.

2. PPBS does not provide any effective operating tools for line managers.

3. PPBS does not provide a mechanism to evaluate the impact of various funding levels for a program or establish priorities among programs and varying levels of program effort.

Pyhrr contrasts PPBS as "basically a macroeconomic, centralized, top-down policy and long range planning tool" [emphasis added], with ZBB as essentially a microeconomic, decentralized, down-top policy and short range management tool. ${ }^{10}$

The compelling attraction of ZBB for many administrators has been, and continues to be, its promise of providing a means by which spending might be held in check, if not reduced, by requiring that the goals of the organization, the programs that have been determined to be most important to achieve those goals, and the alternative methods and costs necessary to carry out those programs, be stated in categorical terms. ZBB promises "a system that rationally [breaks] up all spending requests - both old and new - into understandable, manageable alternatives [to enable] people. . . to discover the truth and falsity in each and [allows] all to compete on equal footing for scarce budget dollars." 11

It would be foolhardy to assert that ZBB or any management/budgeting system, applied by any administrator in any library will produce an administrative millennium. For example, one proponent of $\mathrm{ZBB}$ cautions against use of ZBB if an organization has a total annual budget of less than $\$ 1,000,000$, fewer than seventy-five staff members, or if other major changes are taking place in the organization. ${ }^{12}$ It would be equally unwise, however, to give comfort to the seat-of-thepants manager whose intuitive assessments of the library's political environment are the primary, if not the sole, basis for planning and resource allocation. To be sure, "people are more potent than numbers or logic."13 But to suggest that so-called commonsense management has a monopoly on sensitivity to people or that all comprehensive management/budgeting systems are wildly impractical, even antithetical to effective administration, risks offering unwarranted comfort to the administrative Luddite.

However important may be the choice of a structure or technique in budgeting, it is clearly the use of budgeting structure and technique by administrators that is most important. Budgetary planning "is too critical to be left to the casual, infrequent attention of someone whose main interests lie elsewhere,"14 and if the leadership of a library does not have the will to manage or the ability to identify and articulate the central issues that face the library, techniques of budgetary formulation will matter little. However, if administrators are willing to consider the possibility that library operations and services might be changed for the better, or if serious budgetary reductions are expected, then the choice of a framework for budgeting becomes most important.

Practical application of ZBB in large service organizations is not yet so widespread or advanced that any firm assessment of its potential usefulness in libraries may reasonably be made. The examples cited in Chen's work represent either very recent (i.e., post-1977) implementation of ZBB or very small (corporate and college) library experience. No large public, academic, or research library experience is included.

It is clear that the implementation of $\mathrm{ZBB}$ in any large labor-intensive service organization, in the "third sector," to use Drucker's term, clearly would present some special problems:

1. Many unit managers - and administrators - have not been prepared to evaluate rigorously and rank the relative benefits and effectiveness of service programs.

2. Many unit managers are notably reluctant to propose budgeting changes that would require significant shifts in the assign- 
ments of staff members or in the pattern of staffing generally.

3. The organization's reward system for managers-and for their units - has traditionally been one of adding money to most unit budgets, not reducing them, as presumably would be encouraged with rigorous implementation of ZBB.

4. Since most libraries operate as a subordinate unit of a larger organization, the choice of what budgeting structure is to be used is rarely at the discretion of the library; if ZBB is not adopted at the higher organizational level, the library's staff might well be faced with an unacceptably high level of paperwork to prepare budgets in two different formats.
Yet the elements of ZBB theory remain compelling simply because they require managers to manage, i.e., to "identify and analyze what . . . they plan . . to do in total, set goals and objectives, and evaluate changing responsibilities and work loads - not after the budgeting process, but during it, as an integral part of the process." 15

There is, then, as with most "new" systems, nothing truly new in ZBB. But ZBB does provide a well-structured mechanism for management decision making at a time when funding constraints present special challenges for library budget makers. For that reason, if for no other, the principles of $\mathrm{ZBB}$, if not the process itself, continue to merit careful attention by librarians.

\section{REFERENCES}

1. Peter I. Drucker, "Managing the "Third Sector," "Wall Street Journal (Oct. 3, 1978), p.26.

2. Herbert S. White, "Library Management in the Tight Budget Seventies," Bulletin of the Medical Library Association 65:12 (Jan. 1977).

3. Murray S. Martin, Budgetary Control in Academic Libraries (Greenwich, Conn.: JAI Press, 1978).

4. Charles W. Sargent, "Zero-Base Budgeting and the Library," Bulletin of the Medical Library Association 66:31-35 (Jan. 1978).

5. Diane C. Parker and Eric J. Carpenter, "ZeroBase Budget Approach to Staff Justification for a Combined Reference and Collection Development Department," in Robert D. Stueart and Richard D. Johnson, eds., New Horizons for Academic Libraries (New York: K. G. Saur, 1979), p.472-82.

6. Ching-chih Chen, Zero-Base Budgeting in Library Management: A Manual for Librarians (Phoenix, Ariz.: Oryx Press, 1980).

7. Peter A. Pyhrr, Zero-Base Budgeting: A Practical Tool for Evaluating Expenses (New York: Wiley, 1973).

8. Verne B. Lewis, "Toward a Theory of Budgeting," in Fremont J. Lyden and Ernest G. Miller, eds., Planning, Programming, Budget- ing: A Systems Approach to Management (2d ed.; Chicago: Rand McNally, 1972), p.226.

9. For several useful statements about experience with ZBB, consult Compendium of Materials on Zero-Base Budgeting in the States, prepared for the U.S. Senate Committee on Government Operations (Washington, D.C.: U.S. Gov. Print. Off., 1977). The reports on ZBB in New Jersey and New Mexico are good examples of contrasting experience with $\mathrm{ZBB}$.

10. Pyhrr, Zero-Base Budgeting: A Practical Management Tool for Evaluating Expenses, p.149.

11. Logan M. Cheek, Zero-Base Budgeting Comes of Age: What It Is and What It Takes to Make It Work (New York: Amacom, 1977), p.4.

12. Paul J. Stonich, Zero-Base Planning and Budgeting: Improved Cost Control and Resource Allocation (Homewood, Ill.: Dow JonesIrwin, 1977), p.10-11.

13. Richard DeGennaro, "Library Administration \& New Management Systems," Library Journal 103:2482 (Dec. 15, 1978).

14. Murray S. Martin, "Budgetary Strategies: Coping with a Changing Fiscal Environment," Journal of Academic Librarianship 2:301 (Jan. 1977).

15. Pyhrr, Zero-Base Budgeting: A Practical Management Tool for Evaluating Expenses, p.x. 